\title{
378. 外耳道加圧による耳鳴治療
}

\section{渡辺建介・佐藤玲子・龟井知春（東医歯大）}

目的 耳鳴の治療法として種々の試みがなされてい る.キシロカインを鼓室内に注入したり静注する方法, maskerによる方法などいずれも一時的には効果が認 められるが永続性の点では問題がある。しかもその都 度耳鼻科を受診したり, 器具を装着しなければならな い，今回我々は患者が自分で行える方法で耳鳴を軽減 する方法を見い出だしたので報告した。この方法も一 時的にしか効果がなかったが, 耳鳴が強くなった時や 気になってイライラする時に随時自分で行うことが出 来る利点がある。

方法 耳鳴のある患者で耳鳴の種類をピッチマッチ 法とラウドネスバランス法で特定できた患者について 検索を行った。聑珠を外耳道側に倒し外耳道を密封す る. 耳珠の上から指で患者が痛がらない程度の圧(陽 圧約 $8 \mathrm{mmHg}$, 陰圧約 $2 \mathrm{mmHg}$ ） 10 回かける (図). 外耳道加圧が終わった直後に再びラウドネスバランス 法で耳鳴の大きさを測定し耳鳴の改善の有無を評価し た.

結果 49例の患者のうちラウドネスバランス法で $10 \mathrm{~dB}$ 以上耳鳴の大きさが改善した症例は11例（22 $\%), 5 \mathrm{~dB}$ 改善した症例は16例 (33\%)，無効例は20例 (41\%)，悪化例は 2 例（4\%）であった。 $5 \mathrm{~dB}$ 以上の 耳鳴改善例は全例自覚的にも改善老認めた。またこの 手技を加えた後施行前の聴力レベルよりも小さな音圧 の耳鳴を訴えた症例も数例あり，骨導聴力が一過性に 改善したことを示唆しているものと考えられた。 $5 \mathrm{~dB}$

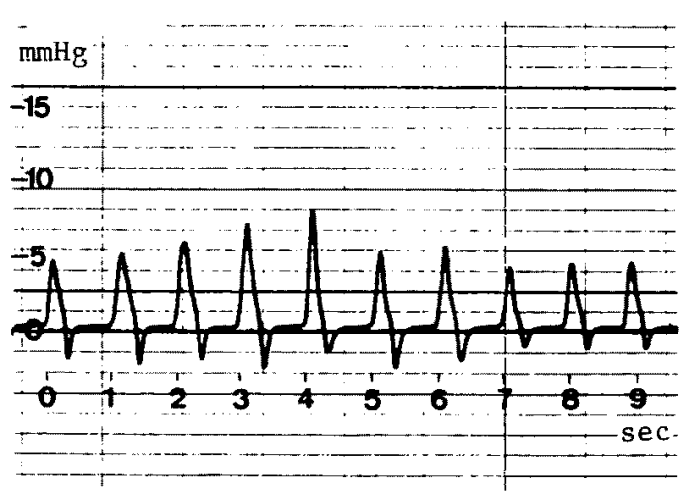

図

以上の耳鳴改善27例（55\%）を有効とした。 $8000 \mathrm{~Hz}$ の 耳鳴は有効例17例 $(63 \%)$ ，無効例 $(86 \%)$ と無効例に 多い傾向を認めた。疾患別や難聴の程度では有効例と 無効例にほとんど差を認めなかった。今後症例を増や して診断の上での有用性についても検討を加えたいと 思っている。筫問 調 重昭(福岡大).耳珠珐迫 による耳鳴変化のメカニズムは。応答 耳鳴が消 失した症例は 2 例あった。一時的だが効果は確加にあ ると思う。追加 溝呂木健二(横浜市). Tragus 圧して外耳加圧によって耳鳴が軽隇，消失する治療法 には非常に良いと思い敬意を表する。

\section{9. 外耳道加圧によるWeber 法の偏倚について}

\section{溝吕木健二（横浜市）}

緒言 Leipsig大学のErnsct Heinrich 教授 (1795 1878), Wilhelm Weber が, 「Weber $の$ 実験」 の発表より，1845年 Jean Pierre Bonnafont が Weber 法の実験を臨床に応用し, それ以来 Weber 法が普及 した. 聴力検查においてオージオメータが急速な進歩 したが，音叉を用いるWeber 法が1970年に入ってか ら，ヨーロッパを中心に音叉検査が見直され，新しい 観点から音叉による検査が再検討されて来た。音叉は 医師が患者に直接，接して施行する検查はその重要性 を感じる。ロンドン大学の Hinchelife, 生駒, 両教授 は, 音叉検査について造詣深く, 耳鼻領域に拈ける音 叉検查も見直す必要があると述べている。栚来の音叉 検查も捨て難いものがある。. 巳に私は，1945年におい て何故正常頭位にて聴力検查を行っていることについ て疑問を抱き, 頭位の変化, 頸部捻転, 眼球圧迫によ るWeber 法を唡査したところ，偏倚する場合がある
ことを検索した，耳鼻咽喉科学会総会において 4 回に わたり発表した，本問題に，牧田，木村，両氏はそれ ぞれの角度に扔いて偏倚について述べている。

万法 そこで, 外耳道加圧した場合の偏倚は如何と 考元，正常人100人にポリツエルゴム球にて加圧し，C 音叉を使用して，Weber 法の変動を観察した。

結果 100 例中偏倚のないもの31例, 加圧側に偏倚し たもの69例。概极 $2 / 3$ 強は偏倚し，約 $1 / 3$ は不変であっ た.

考按 頭位の変化, 形部捻転, 眼球圧迫により, Weber 法の偏倚に影響があることは実証されたが，外 耳道加圧によるWeber 法の偏倚は, Gelle 法における 压の変化が音の変動におけるアブミ骨底の一時的の固 着の説明が加圧による偏倚を来す要因と思われた。な お上記要因の変化が, 解剖学的の要素に関して, 位置 変化により，位相差を生じて，偏倚を来すことを考え 
られ，なお検索を要し，文献的にはある程度の説明は されているが，的確なことは，いまだ解明されていな い。しかしながら，外耳道加圧によって，直る程度 Weber 法の偏倚を認めた。質問 調 重昭(福岡
大).外耳道を加圧しなくて，ポリッエル球をあてただ けでもWeber法の偏倚は起こるのではないか. 応答 御追加有難とうございます。

\section{0．小児機能性聴覚障害症例に対する箱庭療法の試み（第 3 報）}

\section{三好 彰・三好 進・石川饥い子（三好病院）}

(1)小児の機能性聴覚障害は，近年増加傾向にあると言 われる。けれどもこれまでは，その背景に存在する心 理的葛藤（心因）へのアプローチや対応が，必ずしも 十分とは言えなかった。

(2)演者らはこの傾向に疑問を抱き，小児の心因性疾患 に対して箱庭療法を応用, 背景にある心理的葛藤（心 因）に関して積極的なアプローチを試みて来た。ここ ではこれまで演者らが报って来た幾つかの症例の中か ら，ある程度病態の輪郭が明確となった 8 症例につい て検討を加えた。

(3)性別では 8 例中 5 例が男子，3例が女子であった。 年齢は 8 歳が 1 例, 10 歳が 2 例, 11 歳が 2 例, 12 歳が 3 例であった。聴覚障害耳は両側が 5 例，片側が 3 例 であった。眼科的に注視野異常が 5 例, 正常が 3 例で， 異常例中治療と共に正常化した例が 2 例あった。因 として家庭内の葛藤が明らかになった例が 6 例，うち 学校にも募藤の存在した例が 1 例あった。残りの 2 例 も，家庭内に方ける心理的葛藤の存在を疑わしめた。 これら 8 例中全例が，箱庭に己の心理的葛藤を投射し ていた.

(4)以前から報告して来たごとく箱庭療法は小児機能性 聴覚障害の, 㖣断・治療・症例とのラポール形成に有 用である．箱庭療法から推測されるこの病態の本質は 小児とそれを取り巻く環境との粗撂，そしてそれに起
因する心理的葛藤である，機能性聴賞障害あるいはし ばしばこの病態に併存する機能性視覚障害は，小児に おける心理的葛藤のアラーム・サインであると考え机 ばならない。

(5)従ってこの病態への対応は第一に，小児の心理的葛 藤をどう捉えどう対処して行くか，であると思われる。 つまりこれまで時に行われて来たごとき，聴覚域値の 変動の検查とその正常化のみを目的とする対応には, 疑問が残る、それ杜単にアラーム・サインに過きない からである。

(6)我々は火災報知器が鳴ったら，まず本質である火災 を消すことを考え斿ばならない。アラーム・サインで ある報知器を止めても，火災が消えた訳ではないのた 加ら. 質問 調 重昭(福岡大)。箱庭療法の方法 論として，検查と治療のどちらに重きを置いているの か. 応答 日本における箱庭療法の歴史は浅く, 学会を結成していまだ 4 年目である.今後本法を活用 しての診断・治療が発展して行くものと思われる。

質問 古沢慎一(北里大)，機能性難聴を診た時の耳鼻 科医としての対処の仕方について。応答 耳鼻科 医であっても聴覚域値の変動のみに気をとられること なく，症例全体を人間として把握することが必要と考 えている.

\section{1. 外耳・中耳・内耳奇形を認めた Crouzon 症候群の 1 症例}

山辺 習・赤池徽哉・相川

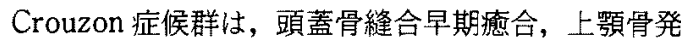
育不全, 両眼隔離, 眼球突出を主徴とする常染色体優 性遺伝の疾患である。今回われわれは，右伝音難聴を 呈し，外耳，中耳，内耳奇形を認めた Crouzon 症候群 の1症例を経験したので報告した。

症例は 6 歳の男児で, 母親がCrouzon 症候群の診断 を受けて扔り，本症例も近医にて同症候群と診断され ている. 近医で右外耳道狭窄と耳垢塞栓にて定期的加 療を受けていたが，除去困難となり耳痛も出現してき たため当科を紹介された。受診時外耳道の狭窄と耳垢 塞栓を認め，外耳道炎も併発していた。抗生剂の投与 等で炎症を消退させ耳垢を除去するも鼓膜の明視は困

\section{通・大谷 嚴（福島医大）}

難であった。耳垢除去後の聴力検査で右伝音難聴を認 め，ティンパノグラムは右 B-typeであった. X-Pおよ び CT 検査で種々の所見が認められた。外耳道の狭哄 は軟骨部に認められ，骨部外耳道に狭窄は認めなかっ た。また，鼓膜部位に骨性の隔壁が存在していた。耳 小骨には画像診断上著变を認めなかった。内耳では， 両側とも前庭の拡大を認め, 外側半規管は前庭より軽 度笑出するのみで arch を形成していなかった. 蝸牛, 内耳道には著変を認めなかった，外耳道狭窄にたいし て, 外耳道形成術を施行した。術中所見で鼓膜部位に 骨性の隔壁を認め，その中央に一部膜性のものが認め られた。術後の平衡機能検査では，Romberg, Mann 